WANL-TME-340

MAY 6, 1963

\title{
REQUEST FOR TEST CELL "A" MODIFICATIONS
}

\section{HASTER}

\section{Astronuclear Laboratory Westinghouse Electric Corporation}




\section{DISCLAIMER}

This report was prepared as an account of work sponsored by an agency of the United States Government. Neither the United States Government nor any agency Thereof, nor any of their employees, makes any warranty, express or implied, or assumes any legal liability or responsibility for the accuracy, completeness, or usefulness of any information, apparatus, product, or process disclosed, or represents that its use would not infringe privately owned rights. Reference herein to any specific commercial product, process, or service by trade name, trademark, manufacturer, or otherwise does not necessarily constitute or imply its endorsement, recommendation, or favoring by the United States Government or any agency thereof. The views and opinions of authors expressed herein do not necessarily state or reflect those of the United States Government or any agency thereof. 


\section{DISCLAIMER}

Portions of this document may be illegible in electronic image products. Images are produced from the best available original document. 


\section{REQUESTS FOR TEST}

\section{CELL A MODIFICATIONS}

This report was prepared an accoulit of work sponsored by the United Sidtes Government Neather the United States nor the United States Atomi Energy Commission, not any of their enplovees, nor any of ther contractors, subcontractors or their employees meges any wars, subcontrus ex makes any warranty, express or imohed, or assumes any

legal liability or responsibiht for the alcuract, com

pleteness or usctulness of any information apparatus

product or process disclosed, or represents that its use would not infringe privately owned rights

WANL-TME- 340

May 6, 1963

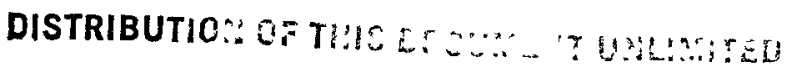




\section{TABLE OF CONTENTS}

\subsection{INTRODUCTION}

2.0 NEEDED CAPABILITIES AND MODIFICATIONS REQUIRED IN CONTRACT YEAR 1963

2.1 Data Acquisition System

2.2 Photographic Equipment

2.3 Movable Reactor Shed and Igniter
Page 2

Page 6

Page 7

3.0 NEEDED CAPABILITIES AND MODIFICATIONS REQUIRED DURING CONTRACT YEAR 1964

3.1 Additional FR-600 Tape Recorders

3.2 Hydraulic System Back-up Pump

3.3 Gaseous Hydrogen Cool down Header

3.4 Helium Process Gas Header

3.5 Photographic Equipment

3.6 Emergency Cool down Reserve System

3.7 Relocation of Liquid Hydrogen Propellant Line
Page 9

Page 10

Page 10

Page 11

Page 12

Page 13

Page 14

4.0 NEEDED CAPABILITIES AND MODIFICATIONS TO BE PROVIDED THROUGH LASL

4.1 Data Reduction System

Page 16

4.2 ACV-3 Actuator Replacement

Page 19

4.3 Single Phase Propellant Feed System

Page 19

4.4 Liquid Hydrogen Turbo-Pump

Page 20

4.5 Modified Signal Conditioners

Page 20

4.6 Additional Control Cables

Page 20 
4.7 Nuclear Instrumentation Facilities

4.8 Flow Pipe for Pre-Operational Tests

4.9 Data Acquisition Equipment
Page 20

Page 21

Page 21

\subsection{COST TABULATIONS}

6.0 COST SUMMARY

7.0 MODIFICATIONS PRESENTED IN WANL TME-279 FOR WHICH NO FUNDS ARE REQUESTED

7.1 Nuclear Instrumentation Systems

Page 25

7.2 Control Systems

Page 25

7.3 Instrumentation Systems

Page 25

7.4 Duplicate Diesel Generator Set

Page 25 
1.0 Introduction

WANL-TME-279, "Recommended Modifications to Extend Test Cell 'A' Capabilities for NRX Testing", dated March 3, 1963, was distributed to SNPO, AGC, and LASL representatives in a meeting at WANL on March 20, 1963. SNPO representatives pointed out the stringency of funding limitations for contract year 1963.

As a result of the meeting and subsequent follow-up, the modifications delineated in WANL-TME-279 have been reviewed and subdivided into funding categories as follows:

1. Modifications for which SNPO-C funds are requested during contract year 1963

2. Modifications for which SNPO-C funds are requested during contract year 1964.

3. Modifications which LASL will perform

4. Modifications for which no additional funds are requested

This report is intended to serve as a request to SNPO to allocate the necessary funds for use in contract years 1963 and 1964 based on the current status of known modifications. 
2.0 Needed Capabilities and Modifications Required During Contract Year 1963

2.1 Data Acquisition Systems

The information given here assumes that modifications outlined in Aerojet-

General Report 2317, pages 43 and 44 are completed, including separation of 400 cycle power supplies, before start of NRX-A1 tests.

\subsubsection{Needed Capabilities}

During NRX testing, facilities are required to record data up to approximately 800 information channels which include reactor and facilities measurements. All diagnostic type data will be recorded on magnetic tape through channels of appropriate bandwidth. Selected data channels will also be recorded on Sanborn charts or oscillographs. In addition to these kinescope and voice records will be required for each NRX test, however, only the diagnostic data acquisition equipment requires modification or supplemental equipment.

\subsubsection{NRX-A1 Tests (Cold Tests)}

For these tests 195 channels of wide band (W.B.)* data and 500 channels of multiplexed, narrow band

*For the purposes of data recordings as found in this document, narrow band (N.B.) is defined as a record generally not exceeding ten (10) cycles per second, (10 cps), and recordable (without special provisions) on the existing PAM/FM data. 


\subsubsection{Cont.}

(N.B.) data will be required to meet test objectives. The channels and frequency response limits have been tentatively identified as 13 channels each of $300,450,600,790$ and 1,050 cps. See Figure 1 for block diagram of recording system. It is proposed that procurement of 130 wide band channels be initiated immediately. It is anticipated that the results of the KIWI cold flow tests will yield useful data for NRX. The total number of wide band channels will depend on the outcome of KIWI and NRX cold flow tests and additional design and analysis influences. A listing and justification for uses of wide band data channels is given in WANL TNR-097, "Preliminary NRX-A1 Test Plan, Rev. 0".

\subsection{Equipment Required}

Magnetic tape recording capability exists at Test Cell "A" using the above combination of W.B. and N. B. data if the back-up recorders are used for prime data and since NRX-Al test run durations are so short, it is not considered necessary to provide tape recording back-up. 


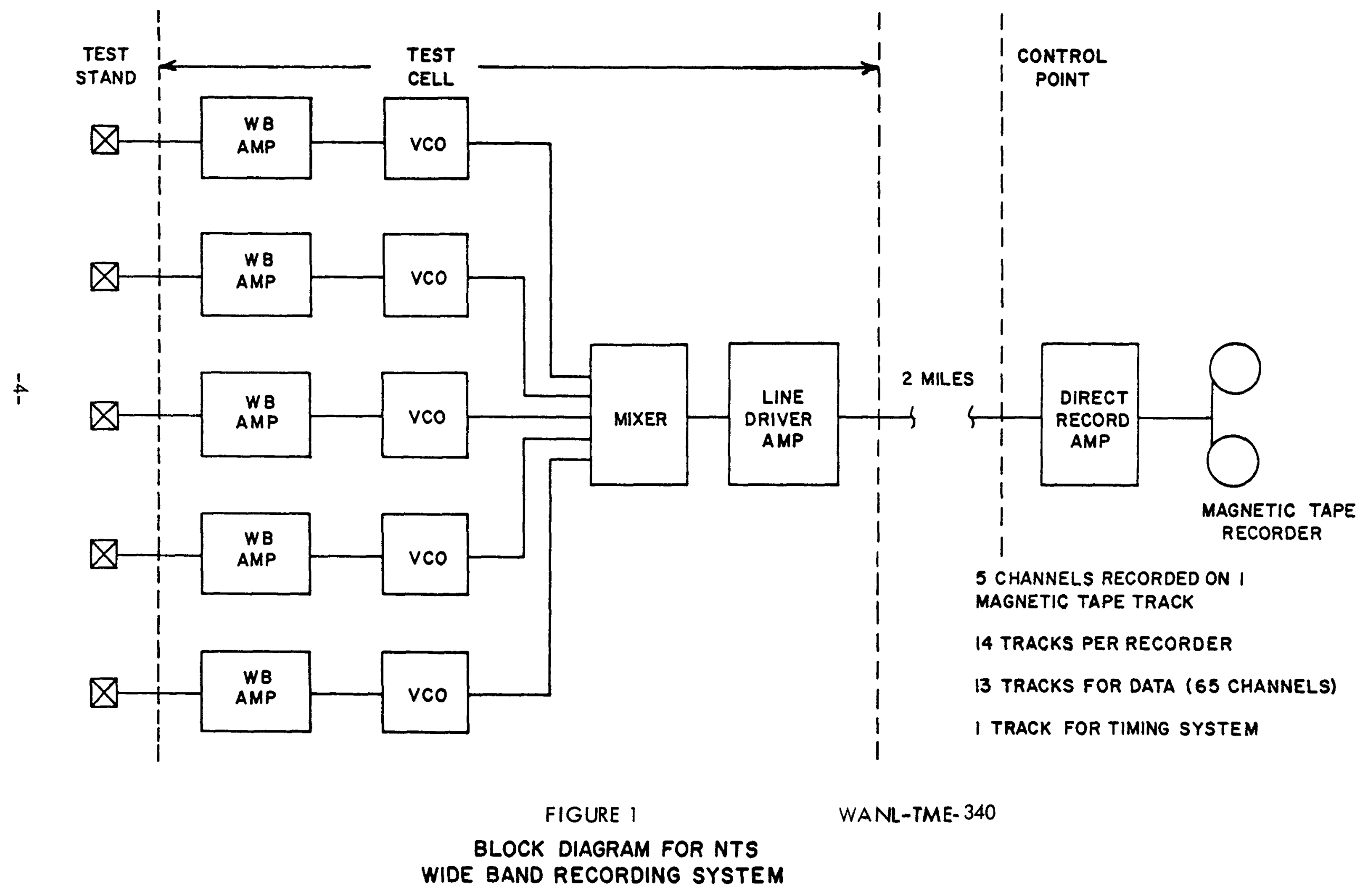


2.1.1.1.1 Cont.

On this basis, the equipment required for 130 channels of wide band is:

130 Wide band amplifiers, Dynamics Corporation, Model 2640 or Neff 107

9 Voltage Control Oscillator (VCO) systems,

Vidar, Inc., Type S-60

Eight of which consist of:

15 VCO's

3 Mixer networks

One of which consists of:

10 VCO's

2 Mixer networks

and 26 Line Drive amplifiers

For 195 channels of wide band the equipment required is:

195 Wide band amplifiers, Dynamics Corporation, Model 2640 or Neff 107

13 Voltage Control Oscillator (VCO) systems, Vidar, Inc., Type S-60 consisting each of: 15 VCO's

3 Mixer networks

39 Line Drive Amplifiers 


\subsubsection{NRX-A2 Tests}

For NRX-A2 tests, it will be necessary to record wide band information up to the capacity of one tape recorder (about 65 channels). In addition, approximately 700 channels of multiplexed information (includes facility data) will be recorded. No additional recording equipment above NRX-A 1 requirements is anticipated for NRX-A2 except for backup recorders.

\subsubsection{Cost Estimate}

130 Channels of Wide Band Equipment

195 Channels of Wide Band Equipment
$\$ 240,100$

$\$ 354,900$

\subsubsection{Schedule Estimate - Five (5) months}

\subsection{Photographic Equipment}

The photographic requirements for the NRX-Al test are not as stringent as those for a hot run. This is because cold flow test runs are short in duration and radiation resistant film record backup is not needed. To provide adequate coverage of NRX-Al, it is recommended that the following equipment be supplied:

a. Four (4) high speed movie cameras

$$
\text { Size - } 16 \mathrm{~mm}
$$$$
\text { Speed - } 100 \text { frames/sec. }
$$

Film capacity - 1200 feet

Lens - $210 \mathrm{~mm}, \mathrm{f} 3.5$

Accessories - four extra magazines

b. Six normal speed movje cameras

$$
\begin{aligned}
& \text { Size - } 35 \mathrm{~mm} \\
& \text { Speed - } 24 \text { frames/sec. } \\
& \text { Film capacity - } 2000 \mathrm{ft} \text {. } \\
& \text { Lens - } 500 \mathrm{~mm}, \mathrm{f} 6.3
\end{aligned}
$$


Two high speed and three normal speed cameras would be located in each of the bunkers, South and East. The mode of operation for each location will be to run one normal speed camera until its film magazine is almost depleted and then start the second normal speed camera. This will allow for coverage for the entire run. Another normal speed camera would furnish backup. The high speed cameras would be operated to record only pre-selected and unplanned critical events.

Cost estimate $-\$ 70,000$

Note: The above camera requirements do not include a fastax camera for photographing the discharge end of the core since there is no quartz window in the thrust chamber section of the NRX nozzle. If such a window as planned for the KIWI cold flow reactors is incorporated into the $N R X-A l$ nozzle, a camera for viewing this area will have to be provided.

\subsection{Movable Reactor Shed and Reactor Ignite}

\subsubsection{Description}

Recent measurements have shown need for raising the roof of the movable reactor shed. The height of the NRX assembled reactor and nozzle is approximately five (5) feet higher than KIWI B-4A. The increased height of the nozzle will also necessitate a change in position of the rabbit tube and the igniter. 


\subsubsection{Modification}

It is necessary to have the roof of the movable shed raised.

Pre sent plans call for elevating a part of the roof seven (7)

feet. The rabbit tube and igniter must also be raised to

conform with the new dimensions of the test car assembly.

\subsubsection{Cost - Up to $\$ 10,000$}

\subsubsection{Schedule}

This task must be accomplished before NRX-Al. 


\subsection{Needed Capabilities and Modifications Required During Contract Year 1964}

\subsection{Additional FR-600 Tape Recorders}

Wide band recording without multiplexing requires the use of the shared back-up recorders for primary data recording. While the back-up recorders may be used satisfactorily during very short duration cold test, such an arrangement is not satisfactory for the hot test.

In a cold flow test, the recorders are used for a duration of approximately 15 to 20 seconds and the probability of a recorder failing during this short time is unlikely. Multiple cold flow tests are planned, and the loss of a recorder during one of these runs would not cause an irretreivable loss of data..

During a hot flow test, the situation is quite different. The duration of the test is much longer, and it is imperative that the data be recorded during the run as this test cannot be repeated without considerable cost and delay in the program. Therefore, during NRX-A2, it is considered mandatory that backup recorders be available to insure that the data is recorded.

\subsubsection{Required Modification}

(2) FR-600 tape recorders will be required for 130 wide band data channels.

(3) FR-600 tape recorders will be required if 195 wide band data channels are provided.

\subsubsection{Cost}

(2) FR-600 tape recorders

$\$ 100,000$

(3) FR-600 tape recorders

150,000 


\subsubsection{Schedule}

It is estimated that the procurement and installation of this equipment will require four (4) months.

\subsection{Hydraulic System Backup Pump}

The control rods hydraulic system and the valve hydraulic system are completely independent of each other and neither is provided with a backup pump.

\subsubsection{Recommended Modifications}

It is proposed to combine the two (2) hydraulic systems and install two pumps each with the capacity of the combined requirements of both systems. One pump would be run under normal conditions and the second would be a standby. This modification will provide for hydraulic power throughout the tests.

\subsubsection{Cost}

It is estimated that this modification would cost $\$ 15,000$.

\subsubsection{Schedule}

It is estimated that the design, fabrication, installation and checkout would require four (4) months.

\subsection{Gaseous Hydrogen Cooldown Header}

The gaseous hydrogen $\left(\mathrm{GH}_{2}\right)$ cooldown header supplies and controls the flow rate of $\mathrm{GH}_{2}$ from the tank farm to the reactor during a normal shutdown after a power run. The present header is primarily a 6" pipe from the tank farm to the reactor with an $F-4$ filter, $P C V-41$ valve, FE-10 venturi and a section of 3" pipe in the Flow Control Room. 
The maximum flow of the presently installed header is approximately

$20 \mathrm{lb} / \mathrm{sec}$. due to the $\mathrm{FE}-10$ venturi.

\subsubsection{Requirements and Justification}

After the reactor has been operated at full power, the normal shutdown procedure will be to continue liquid hydrogen cooling as long as there is no possibility of liquid entering the core. When this period ends, it will be necessary to switch to gaseous hydrogen cooling. A flow rate of $30 \mathrm{lb} / \mathrm{sec}$. is required at this time for proper cooling.

\subsubsection{Modifications Required to Meet the Requirements}

The modifications required to meet the flow demand of approximately $30 \mathrm{lb} / \mathrm{sec}$ of $\mathrm{GH}_{2}$ would require the replacement of the $\mathrm{FE}-10$ venturi.

\subsubsection{Cost}

It is estimated that this modification will cos $\$ 7,000$.

\subsubsection{Schedule}

It is estimated that three (3) months will be required for design, fabrication, installation and checkout.

\subsection{Helium Process Gas Header}

The helium process gas header supplies and controls the flow of helium from the tank farm to the flow control room. It branches off into smaller lines in the flow control room feeding the various functions suchas inerting and emergency cooling. 
Emergency cooling with helium is used whenever fire threatens to damage the reactor.

\subsubsection{Requirements}

The helium system must be able to take over emergency cooling after scram as soon as the emergency liquid reserve (see section 3.6 ) is exhausted. It must also be able to provide emergency cooling starting at any point during a normal shutdown. In order to do this, a flow rate of $40 \mathrm{lb} / \mathrm{sec}$ is required.

\subsubsection{Modification Required}

The header from the tank farm to the flow control room should be increased from 3" to 6" schedule 160 pipe.

\subsubsection{Cost}

It is estimated that this modification will cost approximately

$$
\$ 65,000 \text {. }
$$

\subsubsection{Schedule}

It is estimated that three (3) months will be required for design, fabrication, installation and checkout of the equipment.

\subsection{Photographic Equipment}

The total photographic equipment requirements for NRX testing were pres ented in AGC report 2317. During contract year 1964, it will be necessary only to add cameras to those bought in contract year 1963 to complete the listing in the above report. 


\subsection{Cont.}

\subsubsection{Cost}

The additional equipment to be purchased in contract year 1964 is estimated to cost $\$ 60,000$.

\subsection{Emergency Cooldown Reserve System}

The loss or failure of the turbo-pump during a power run will cause a scram and loss of $\mathrm{LH}_{2}$ to the reactor. Although there is pressure in the dewars, this pressure is far below the pressure required to supply sufficient $\mathrm{LH}_{2}$ to the reactor during the initial cool down period.

\subsubsection{Requirements and Justification}

The emergency procedure for cooldown of a core such as the NRX-A2 after reaching full power will be to cool with $\mathrm{LH}_{2}$ for about 15 seconds and then switch to gaseous helium. This is necessary because sufficient quantities of cooling gas cannot be forced through the core without exceeding the stress limits. If there is insufficient cooling during the first 15 seconds, the core may be damaged during cooldown to the extent that the true results of the tests will be masked.

Although the maximum power of the NRX-A2 test has not definitely been established, it is important that the facility be capable of supporting full power reactor operation. 


\subsubsection{Modification Needed}

An emergency reserve cooldown system would include a pressurized reserve $\mathrm{LH}_{2}$ dewar installed in the $\mathrm{LH}_{2}$ propellant line between the control valve $A C V-3$ and $O B V-86$. It would be isolated from this line by a valve similar to OBV -86 . Controls and instrumentation will be required in order that the system can be remotely operated from the control point . Pressure, temperature, and tank level indicators and valve controls will be included.

\subsubsection{Cost}

It is estimated that this modification will cost approximately $\$ 181,000$.

\subsubsection{Schedule}

It is estimated that six (6) months will be required for fabrication, installation and checkout of the equipment. WANL must have a vendor selected and approved by October 1, 1963. Vendor is to be supplied with complete component specifications and system requirements.

\subsection{Relocation of Liquid Hydrogen Propellant Line}

The justification for this modification has been given in WANL-TME-279. Because of schedular conflict in the Flow Control Room with other ptanned modifications and fund limitations ${ }_{p}$ it has been moved into the 1964 category. It could be installed and tested between the NRX-A2 and -A3 tests. WANL will complete engineering evaluation during contract year 1963 and the early part of contract year 1964. 


\subsubsection{Cost - $------\$ 50,000$}

\subsubsection{Schedule}

The estimated time for design, installation and checkout is four (4) months. 
4.0 Needed Capabilities and Modifications to be Provided by LASL

\subsection{Data Reduction Systems}

In addition to existing facilities for quick-look information of test results, additional facilities are here recommended to extend and simplify data reduction procedures. At present, the multiplexed (N.B.) data tapes are taken to Los Alamos for reduction; wide band (W. B.) data is played back on strip chart recorders for further data reduction.

\subsubsection{Requirements for Support of NRX-A1 and A2 Tests}

NRDS data reduction facilities require facilities for the following purposes:

a. Quick-look type information for preliminary analysis of test results.

b. Reproduced, time-based, Sanborn and oscillograph data in correctly scaled engineering units for preparation of a data report.

c. Reduced and plotted data according to engineering plan for a complete data report of the narrow band (multiplexed data).

d. Storage and filing systems for original raw data records for safekeeping.

\subsubsection{Data Reduction Systems Modifications}

Continued use of Los Alamos PAM/FM (narrow-band) data reduction facilities will be necessary unless recommended NRDS facilities are completed. 
Nar:ow Band Da*a Reduction (Multiplexed Data)

A proposed Data Tape Flow Chart for NRDS is shown as Figure 2; however, none of the equipment is yet available at NRDS. It is understood that specifications have been written by LASL for the DEMOD (translation), 160A computer, printer and plotter equipment.

Use of LASL equipment located at Los Alamos for NRX data conversion and data reduction is not desirable because when the facilities are not immediately adjacent to the test site, correction of the data tapes becomes very difficult.

Wide Band Data Reduction

At present, quick-look facilities are not available at NRDS or Los Alamos for converting wide band FM/FM data. The facilities as proposed by the Los Alamos Scientific Laboratories for NRDS will include equipment that would convert wide band FM/FM data to an analog form that could be digitalized in the CDC 160-A or recorded on oscillographs. If these facilities are not provided, it will be necessary to transport the FM/FM tapes to the Westinghouse Baltimore Air Arm Division or some other IRIG facility to be converted to digital tapes. On this basis, it would take a minimum of one week before any FM/FM wide band information could be evaluated.

\subsubsection{Schedule Estimate}

It is recommended that the requested computer facilities be installed as soon as possible so that they will be available for the initiation of the NRX reactor tests. 
FIGURE 2

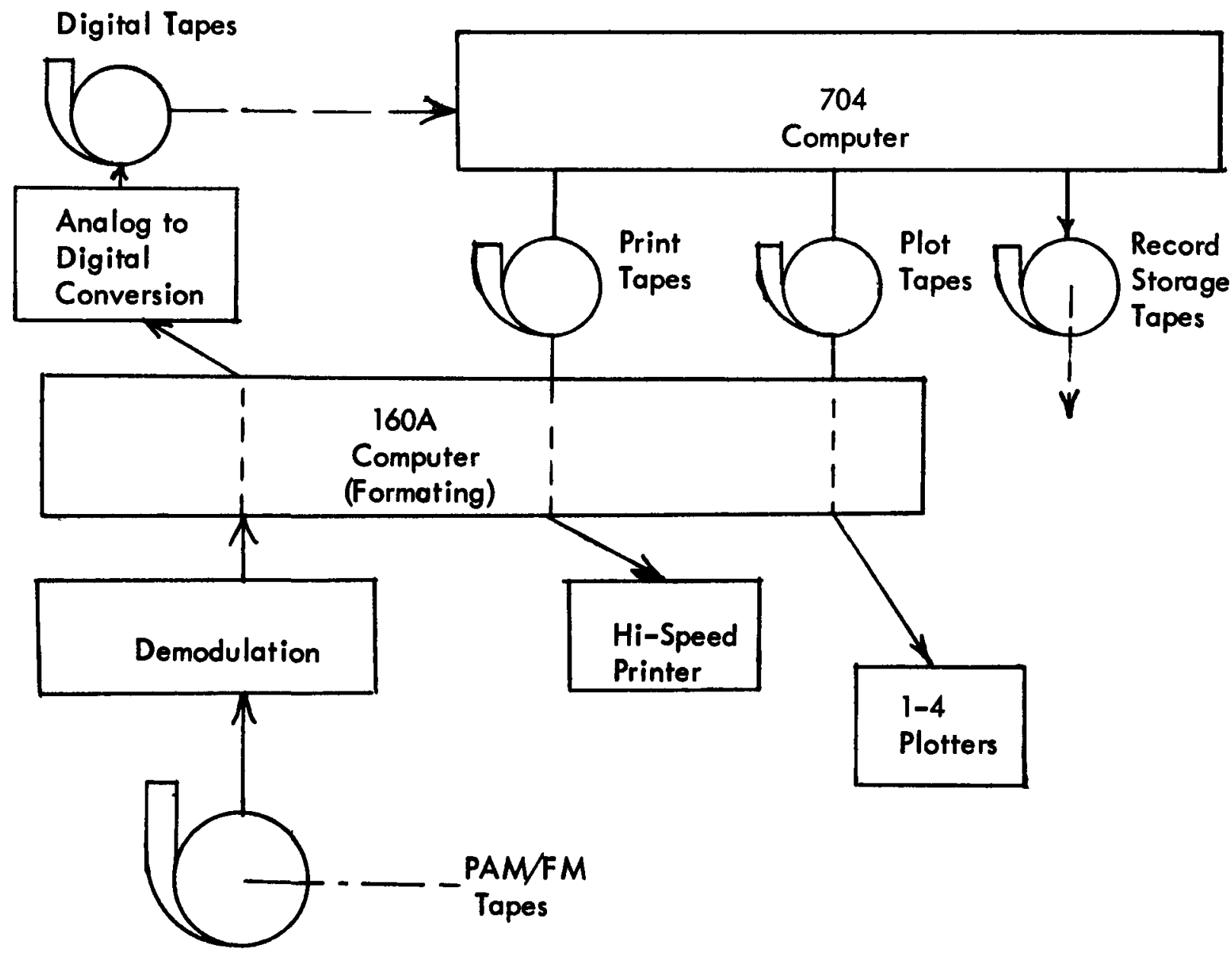

Proposed PAMFM (Narrow Band) Data Tape Flow Chart 


\subsubsection{Requirements and Justification}

The present $A C V-3$ actuator does not have sufficient capacity to insure closing of the valve against back pressure. Because of this inability of the valve to rema in closed on back pressure, hydrostatic testing of the $\mathrm{LH}_{2}$ propellant line cannot be made. In the past, there have been instances where a $\mathrm{LH}_{2}$ line has leaked during operation and if a hydrostatic test were made, these leaks would have been detected.

LASL has agreed to replace the present actuator with one of sufficient capacity to maintain ACV-3 closed against full hydrostatic test pressure.

\subsection{Single Phase Propellant Feed System}

A discussion and justification of the single phase propellant feed system was given in WANL-TME-279.

Two different methods have been proposed as means of obtaining a single phase system. In one of these methods, a heat exchanger transfers heat from ambient hydrogen gas to the liquid propellant, thus heating the gas above the critical temperature.

In the other system, ambient hydrogen gas is mixed directly with the liquid hydrogen propellant which is to be heated.

At the meeting on March 20, LASL stated that they have on hand the major components for the cold gas mixing system. LASL agreed to install the components, design and supply a control system and run check-out tests on the entire system. WANL agreed to prepare and submit requirements for the performance of the system. 


\subsection{Liquid Hydrogen Turbopump}

The need for an installed turbopump and a spare turbopump has been explained and justified in WANL-TME-279.

There are three spare Mark III turbines and LASL has agreed to make at least one available before NRX-A2. LASL has proposed and WANL agrees that the Mark III turbine be replaced by the Mark IX before long duration tests are run (assuming adequate reliability of the Mark IX turbine is proven by then).

\subsection{Modified Signal Conditioners}

The need and justification for the additional 113 signal conditioners was pointed out in WANL-TME-279. LASL agreed to supply these. It is understood that the signal conditioners to be supplied will be modifications of existing equipment.

\subsection{Additional Control Cables}

A list of NRX cable requirements is covered in WANL-TME-279.

Additions planned by LASL have been reviewed by WANL and are considered adequate.

\subsubsection{Schedule}

LASL plans to have the additional control cables installed by the middle of June .

\subsection{Nuclear Instrumentation Facilities}

Proposed modifications in this category were given in WANL-TME-279 in Section 3.3.

LASL has reviewed the nuclear instrumentation at Test Cell " $A$ " and has agreed to make all the racks in the electronics room east of the communication racks available for neutronics instrumentation. They have also agreed 


\subsection{Cont。}

to install shielded cabling from the racks to the detector area of the test cell roof. LASL is also considering changing the detector tank to an arrangement similar to the one in Test Cell "C". WANL agrees that these changes are a satisfactory temporary solution to the neutronics problem. LASL has agreed to continue evaluation of a neutronics room. In particular, they will investigate addition of structural supports in the flow control room to support the weight of a neutronics room on the roof.

\subsection{Flow Pipe for Pre-Operational Tests}

Requirements and justification for this modification has been given in WANL-TME-279. The cost of this item will be covered by operating funds. The estimated cost is less than $\$ 2,000.00$.

\subsection{Data Acquisition}

LASL has agreed if requested to leave eighteen (18) of the existing wide band data channels in Test Cell "A".

This capability is required and WANL requests that these channels be made available for NRX testing. 


\subsection{Cost Tabulation}

The cost breakdowns are given to support the estimated prices shown for each modification. Those breakdowns presented in WANL-TME-279 are not repeated here unless changes have been made.

Wide Band Data Acquisition Equipment (Section 2.1)

130 Amplifiers at $\$ 900$ each

130 Input Filters at $\$ 170$ each

9 Vidar S-60 Systems at $\$ 10,500$ each

26 Line drive amplifiers at $\$ 250$ each

Total

195 Amplifiers at $\$ 900$ each

195 Input filters at $\$ 170$ each

13 Vidar S-60 systems at $\$ 10,500$ each

39 Line drive amplifiers at $\$ 250$ each

Total

Gaseous Hydrogen Cooldown Header (Section 3.3)

FE (Venturi)

Design and Installation

Total
$\$ 117,000$

22,100

94,500

6,500

$\$ 240,100$

$\$ 175,500$

33,150

136,500

9,750

$\$ 354,900$

$\$ 5,000$

$\frac{2,000}{\$ 7,000}$

Time - Three (3) months for design, fabrication, installation and checkout. Emergency Cooldown Reserve System (Section 3.6) 
Emergency Cooldown Reserve System (Section 3.6) Continued

Valves

PRV

RV

AVV

OBV

Piping

Instrumentation

Structural Steel

Installation

Heat Shield

C. P. Modification

Shipping

Sub-total

Contingency

Total
$\$ 6,000$

1,600

5,000

6,000

2,000

9,500

9,250

45,000

4,000

35,000

3,000

$\$ 156,350$

25,000

$\$ 181,350$

Time Six (6) months for fabrication, installation and checkout. 
6.0 Cost Surnmary

$\begin{array}{ll}\begin{array}{c}\text { Contract } \\ \text { Year 1963 }\end{array} & \begin{array}{l}\text { Contract } \\ \text { Year } 1964\end{array} \\ \$ 240,100 & \\ *(\$ 354,900) & \end{array}$

Movable Reactor Shed and Igniter

10,000

Photographic Equipment

$70,000 \$ \$ 60,000$

$\mathrm{GH}_{2}$ Cooldown Header

7,000

Emergency Cooldown Reserve System

181,350

Helium Process Gas Header

65,500

Hydraulic System Backup Pump

15,000

Relocation of $\mathrm{LH}_{2}$ Propellant Line

50,000

Additional FR-600 Tape Recorders

100,000

* $(150,000)$

Totals

\section{$\$ 320,100$}

$\$ 478,850$

* $(\$ 434,900)$

* $(\$ 528,850)$

*Alternate funds required - 195 wide band data channels 
7.0 Modifications Presented in WANL TME-279 for Which No Funds Are $\underline{\text { Requested }}$

7.1 Nuclear Instrumentation Systems

All of the modifications described under this heading in WANL TME-279 are to be carried out by WANL, using Westinghouse contract funds except for instrumentation racks and cabling. These will be provided by LASL (See Section 4.7). For these reasons no additional funds are required.

\subsection{Control Systems}

All of the items listed under this heading in WANL TME-279 are WANL funded except for additional control cabling. This item is being handled by LASL (See Section 4.6). No additional funds are required in this category.

\subsection{Instrumentation Systems}

This group of items was covered in Section 3.5 of WANL TME-279. LASL has already added a backup dewar level indicator. There has been no opportunity to test this equipment, however. If it operates satisfactorily, no additional funds are needed.

\subsection{Duplicate Diesel Generator Set}

A review of the items on the vital bus was carried out by LASL. It was decided by LASL that enough electrical load items can be removed from the vital bus to get by with the existing diesel generator. 


\section{BIBLIOGRAPHY}

1) W. L. Howarth, "NRX-A Shutdown and Cooldown Coolant Usage and Flow Profiles for Test Cell A", WANL-TME-277, January 19, 1963.

2) W. L. Knecht, "Computer Analysis of NRX-A Normal and Emergency Cooldown after a Nominal 20 Minutes of Full Power Operation", WANL-TME-286, February 26, 1963.

3) Letter to H. B. Finger from S. Krasik, "Analog Quick-Look and Digital Processing Facilities for NRDS", May 1, 1963.

4) "WANL Recommended Modifications to Extend Test Cell A Capabilities for NRX Testing" WANL-TME-279, March 6, 1963, Preliminary

5) WANL, "Preliminary NRX-Al Test Plan Rev. O", WANL-TNR-097, April, 1963.

6) H. Norkin and C. Schaedel, "Justification for Wide Band Instrumentation in Test Cell A", WANL-TME-315.

7) Poindexter, A. M., Letter to Mr. Dwight Reilly containing "Minutes of Meeting between AGC, WANL, SNPO-N, SNPO-C, and SNPO-W on March 20, 1963 at WANL", March 28, 1963.

8) AGC Report No. 2317 to AEC - NASA Space Nuclear Propulsion Office, "Modification Specification - Test Cell A in Support of the NRX - NERVA Development" September 5, 1962. 